\title{
New Genealogies of Performance
}

\author{
Laura L. Mielke
}

Acts of Manhood: The Performance of Masculinity on the American Stage, 1828-1865. By Karl M. Kippola. New York: Palgrave Macmillan, 2012. 264 pages. $\$ 85.00$ (cloth).

Pioneer Performances: Staging the Frontier. By Matthew Rebhorn. New York: Oxford University Press, 2012. 224 pages. \$65.00 (cloth).

Spectacles of Reform: Theater and Activism in Nineteenth-Century America. By Amy E. Hughes. Ann Arbor: University of Michigan Press, 2012. 264 pages. \$75.00 (cloth). \$27.95 (paper).

Whiting Up: Whiteface Minstrels and Stage Europeans in African American Performance. By Marvin McAllister. Chapel Hill: University of North Carolina Press, 2011. 352 pages. \$42.00 (cloth). \$29.99 (e-book).

Since the 1990s scholars have produced numerous accounts of Uncle Tom's Cabin as presented on the nineteenth-century stage, emphasizing that more Americans saw Uncle Tom's Cabin performed than ever read Harriet Beecher Stowe's novel. Treatments by Eric Lott, Linda Williams, Sarah Meer, David S. Reynolds, and John W. Frick, among others, consider the political importance and ambiguities of period theatrical adaptations, their entanglement with blackface minstrelsy, their transatlantic reach, and their persistence in twentiethcentury film. The website Uncle Tom's Cabin \& American Culture, directed by Stephen Railton, contains indispensable primary and secondary materials related to theatrical and filmic adaptations. ${ }^{1}$ The best of such accounts of Uncle Tom's Cabin onstage and on-screen offer what Joseph Roach calls "genealogies of performance" that "document—and suspect—the historical transmission and dissemination of cultural practices through collective representations." Such genealogies of performance "draw on the idea of expressive movements as mnemonic reserves" - how a repertoire of movements that is embodied, recorded "in images or words (or in silences between them)," or imagined anew carries along and transforms key elements of a culture. ${ }^{2}$ Anyone who 
has spent time with the images, sounds, and words of the staged Uncle Tom's Cabin steps away with the conviction that the popular drama did not simply manipulate or express audience sentiment. Rather, the wildly variant performances of Uncle Tom's Cabin were part of the culture's rumination (conscious and otherwise) on slavery, African American personhood, and the individual's moral culpability for the suffering of others.

The four books reviewed here present new genealogies of performance practices other than Uncle Tom's Cabin stagings (with one exception) that are no less rooted in nineteenth-century culture and politics and resonate with all that comes after. Marvin McAllister's Whiting Up: Whiteface Minstrels and Stage Europeans in African American Performance documents the practice of African American performers putting on markers of whiteness in highly conscious performances of racial privilege from 1820s South Carolina through our "post-soul" present. Amy E. Hughes's Spectacles of Reform: Theater and Activism in Nineteenth-Century America analyzes mid-nineteenth-century melodrama's "sensation scene" - a spectacular dramatic moment appealing directly to audience emotion —as a phenomenon with terrific physical impact and a range of political valences. Matthew Rebhorn's Pioneer Performances: Staging the Frontier spins a genealogy of the nineteenth-century frontier drama intended to challenge our understanding of the frontier not only as theatrical symbol of ascendant white individualism but also as historical fact. Finally, Karl Kippola's Acts of Manhood: The Performance of Masculinity on the American Stage, 1828-1865 reflects on the opposing forms of white masculinity that vied for dominance of the mid-nineteenth-century stage. Taken together, these books show that (to quote Rebhorn on minstrelsy) "the theater did not so much stage racial construction as it actually theatricalized the construction of race" (73) — and the same holds for gender. As these authors demonstrate, to explore the lineage of whiting up, the sensation scene, the frontier drama, and dramaturgical manhood is to find that theatrical performance does more than represent and participate in existing social practices; it is itself a social practice with far-reaching yet often obscured impact.

McAllister's Whiting Up is a painstakingly researched and revelatory book that recounts a previously neglected history of African Americans' performance of whiteness - not in the sense of "passing" or "acting white" but in acts that depend on audience knowledge of the performer's African American identity and that take up whiteness "as a vehicle for communal and individual definition" (2). In a brilliant introduction, McAllister distinguishes between "two closely related performance modes, whiteface minstrels and stage Europeans" (4), the first involving extratheatrical performances ranging from cakewalks to 
stand-up comedy and the second referring to performances "in conventional dramatic genres and theatrical contexts" (5). He then lays out the four functions of whiting up: to challenge racial hierarchies through "occasionally aggressive satires and parodies of whiteness" (12); to associate oneself or community with positive elements of white culture through "imitation or emulation of whiteness" (13); "to expose systematic white terror in order to warn and potentially transform Afro-America" (14); and finally, "to rehearse new African American identities and establish black style" through the "transfer [of] presumably white traits and practices to black bodies" (16). The six chapters that follow are rich with case studies of whiting up in which the four functions coexist, often in tension with one another. Whiting up, McAllister insists, has a long history and great potential for recuperative and transformative work.

The first two chapters of Whiting $U p$ register the theatricalization of race in the era of slavery. To understand early whiteface performance by the enslaved, McAllister turns to the Charleston African American community's performance of white privilege through the country dance, the white-sponsored cakewalk, and the weekly promenades on Meeting Street, which he deems genteel "rehearsals for freedom" (43). Through these performances, African Americans surreptitiously challenged white power, expropriated white forms, and "establish[ed] black style" (45). James Hewlett, a prominent member of William Brown's African American acting company in 1820s Manhattan (the subject of McAllister's previous book), serves as the exemplar for the early stage European. McAllister considers what it meant for Hewlett, in contrast to white colleagues who put on redface or blackface, to take up "white roles never imagined, written, or intended for [him]" (51) and concludes that Hewlett emulated whiteness to reach professional goals and "to identify, articulate, and advance communal aspirations" (52). Whiting up in the early nineteenth century-be it the caricature of white dance in front of the master or the portrayal of a rebel Scotsman on the New York stage - was a personal and a political act.

McAllister's third chapter ranges across racial humor of the late nineteenthcentury US stage but centers on the actor Bob Cole's performance as a white hobo in The Trip to Coontown (1898), "the first Broadway musical written, produced, and performed solely by African American artists" (75). Coontown takes place in a middle-class African American town that attracts the attention of the curious Willie Wayside. Cole performed the role in thick whiteface, but signaled the hobo "as simultaneously black and white" through his singing of "coon songs," his lower-class status, and his heroism (98). McAllister, no less than his twenty-first-century reader, finds the racial comedy of Coontown disturbing, but insists that the play "could both reinscribe and rewire white- 
ness in America" (107), largely because of the complex performance of Cole and the company's overt assertion of control over theatrical material. Willie Wayside graces the book's cover, a perpetual reminder of the performance mode's ambiguities.

McAllister traces the performance genealogy of whiting up straight through the twentieth century, with chapters on the progressive promise of the stage European in the theater of the 1920s-40s and the 1960s and the political work of whiteface minstrelsy in solo black performances since the 1980s. Hewlett's legacy is apparent in chapter 4's treatment of ambitious African American actors in the first half of the twentieth century who took up European (a.k.a. "Nordic") roles. More specifically, McAllister examines Evelyn Preer's starring role in the Ethiopian Art Theatre's staging of Oscar Wilde's Salome in 1923 and Canada Lee's turn in whiteface as Bosola in the 1946 Broadway production of John Webster's Duchess of Malf. McAllister concludes with palpable sadness, "the Nordic Complex ultimately prevented black and white Americans from accepting anything other than 'jungle utterances' or authentic Negroid art from black performers" (137). Noting the increased success of African American actors in white roles in the 1950s-60s, McAllister then turns in chapter 5 to the stage Europeans in 1960s avant-garde black dramas by Adrienne Kennedy, Douglas Turner Ward, and Leroi Jones/Amiri Baraka. Adapting Daphne A. Brooks's concept of "Afro-alienation acts," or performances that, in the Brechtian tradition, intentionally defamiliarize racial and gender identities through the spectacles of blackness, McAllister explores how spectacles of whiteness in black drama aid African American audiences "by cleansing or containing a whiteness that has defined and devalued blackness" (199).

In the final chapter on black solo performance since the 1980s, McAllister deftly brings together the many strands of the whiting-up genealogy from the 1820 s on. His argument is that stand-up comics Jackie "Moms" Mabley, Dick Gregory, Richard Pryor, and Dave Chappelle and performance artists Whoopi Goldberg, Anna Deavere Smith, and Sarah Jones "integrated a traditionally divisive whiteness into productive play and friendly relations with an equal and hardly deficient blackness" (203). These performers, like their Charlestonian predecessors, take an ethnographic approach to comedy, sharing through whiteface performance their observations of racial, gender, and class identity formations. This "white people be like" comedy at its worst is "Manichean" (223), strengthening rather than challenging stereotype, but McAllister claims that the performers on which he focuses "break and remake American society" through "serious cross-racial play" (248). In this capacious and humane study, McAllister affirms that, despite the legacy of blackface minstrelsy, and because 
of the legacy of whiting up, "We can create cross-cultural commodities that ethically reflect and thoroughly entertain a fully democratized nation" (264).

With Spectacles of Reform, winner of the 2013 American Society for Theatre Research Barnard Hewitt Award, Hughes has similarly paired probing analysis with meticulous research to make visible a vital American performance genealogy. Spectacles of Reform is a beautifully written and deliciously digressive account of how and why spectacle works on the body to political ends. Hughes focuses in particular on three sensation scenes that originated in mid-nineteenth-century theatrical melodrama- "the drunkard temporarily experiencing insanity, the fugitive slave mother dashing across a river, and the heroine saving a man tied to the railroad tracks" (5) —and follows the ripples of these stagings out into the broader culture of reform, where spectacle registers in material and print culture. Hughes defines the oft-neglected phenomenon of spectacle with reference to the visual, intensity, and excess. Important to this treatment is Hughes's examination of the body as/in/at the spectacle: the body can serve as spectacle, participate in spectacle, and look atspectacle. In an introduction that expands on this taxonomy, she argues that spectacle produces potentially transformative affect because the body "serves as the epicenter of meaning" (44). But the power of such affect and the potentially taboo quality of excess do not guarantee the tenor of political work accomplished by spectacle. Hughes sets out to "imagine how these disparate spectacular scenes mobilized affect for conservative, progressive, or equivocal ends" (45).

In chapter 2 Hughes looks to W. H. Smith's The Drunkard (1844) for a foundational scene of "spectacular insanity," the delirium tremens (d.t.'s). Through a discussion of the temperance movement and the popular profile of the drunkard as a husband or father whose habits threaten the well-being of his dependents, Hughes establishes the intensely conservative nature of the stage temperance message. The d.t.'s spectacle attracted eager audiences to the theater and to appearances by the popular temperance lecturer John B. Gough, who re-created the d.t.'s in his orations. By showcasing the drunkard's "deplorable failure to stay within the boundaries of middle-class normalcy," these scenes "reinforced the orderly middle-class body in a powerful and visceral way" $(84,85)$. In the next chapter, Hughes finds the political work of the scene from Stowe's Uncle Tom's Cabin (1852) of Eliza crossing the Ohio River on ice floes while clutching to her young son far more ambiguous, largely because of its transformations onstage, in print, and in material culture. Stowe first penned the scene as emblematic of the moral dilemma posed by the Fugitive Slave Act in 1850; as Hughes argues with reference to numerous textual and visual examples, it "was shaped and inspired by emergent, complicated ideas 
regarding the transformation of property to person through escape" (103). Hughes notes the tremendous irony that "refusing to serve at the center of a spectacle [on the auction block], Eliza becomes the spectacle through escape" (115-16) — and as such, Eliza was available for adaptation and consumption by those less concerned with overturning the Fugitive Slave Act than with genteel domesticity.

Having highlighted the conservative and ambiguous political work of spectacle in temperance and antislavery dramas, Hughes turns to an unlikely source for a progressive sensation scene. The railroad rescue, which first appeared in Augustin Daly's Under the Gaslight (1867), has become shorthand for the excess of melodrama, but as Hughes shows, "the image loaded in our minds today" - of a woman tied to railroad tracks and saved at the last minute by the male hero- "is a distorted echo, ritual, and residue of the premier spectacular instant, repeated and re-formed over time" (152). In Daly's drama, a one-armed Civil War veteran named Snorky is bound to the tracks, and a young woman named Laura uses an axe first to free herself from confinement and then to free Snorky in the nick of time. For his part, Snorky recognizes the political implications of Laura's heroism, declaring, "And these are the women who ain't to have the vote!" (quoted on 119). Refusing to dismiss Snorky's assertion, as others have done, Hughes painstakingly forwards a progressive interpretation of the scene through discussions of the passage of the Fourteenth Amendment, the women's suffrage movement, the discourse of true womanhood, the image of the citizen-soldier, and the gendered and nationalistic valences of the American axe. Yet, Hughes admits, the question remains as to why, over time, Laura swapped places with Snorky in popular memory. Hughes makes some suggestions but is concerned less with accounting for the mutation than with fleshing out a genealogy that makes visible the scene's buried potential as a feminist vehicle. Spectacles of Reform closes with Hughes's reflection on the perpetual relevance of such sensation scenes, which are "embedded in the public imagination" (156). With reference to two recent nontheatrical spectacles-pilot Chesley B. Sullenberger III's emergency landing of US Airways Flight 1549 in the Hudson River and Nadya Suleman's delivery of octuplets-Hughes prompts us to consider how "contemporary entertainment culture still harnesses the affective dynamism of spectacle to inspire and discipline US citizens" (165).

Rebhorn's ambitious Pioneer Performances sets out to revise both US theater history and one of the most contested concepts in US historiography: the frontier. For Rebhorn, the frontier is not a place or a process (two options entertained by scholars) but "a set of performance practices conditioned by 
history and geography" (20). As Hughes documents the political malleability of the sensation scene, so Rebhorn emphasizes the conflicting performance practices that give shape to the American frontier and dramatic form. In the late nineteenth-century, Buffalo Bill Cody influentially performed the frontier as a site where violence secured civilization from savagery. But Cody's American Indian contemporary, Gowongo Mohawk, staged a contrasting idea when she cross-dressed to star as the eponymous hero of Wep-Ton-No-Mah, the Indian Carrier. The freedom of the frontier, as theatricalized by Mohawk and others, could actually "undercut the central tenets of Manifest Destiny" (14); and frontier dramas did not necessarily or consistently uphold the imperial vision. In chapters on five frontier dramas from the 1820 s to the 1870 s, Rebhorn highlights the transformative freedom and aesthetic innovation the frontier affords.

Chapters 1 and 2 consider John Augustus Stone's Metamora (1829) and James Kirke Paulding's Lion of the West (1831), both of which Rebhorn reads as subverting key cultural concepts of the era through their creative engagement with the frontier as "unsettled and unsettling" (26). In his redface performance as the American Indian leader Metamora, the Jacksonian star Edwin Forrest challenged prevailing elocutionary practice and what Rebhorn deems its "grammar of the passions" (31). For Rebhorn, Forrest's volatile yet heroic portrayal of Metamora, developed partly through his time spent with the Choctaw chieftain Push-ma-ta-ha, broke elocutionary decorum and signaled resistance to rather than complicity with imperial ideology. As Forrest's style undermined a vision of "civilization" as inevitably ascendant, the next chapter argues, so the physical excesses of the frontiersman Nimrod Wildfire in Lion of the West rejected the conservative European aesthetic of the sublime as inappropriate for the American landscape. In its place, Wildfire inaugurates a new theatrical genre resting in delight rather than fear: "the American melodrama of wonder" (50). Key to Rebhorn's reading of Lion of the West is its sense of openness and potential-how "the frontier functions as a fantasy of possible ideological and aesthetic formations not yet realized in the 1820s and 1830s" (70), including resistance to the ideology of Manifest Destiny.

Rebhorn takes up the unreadability of race in chapters 3 and 4 through examinations of T. D. Rice's minstrel farce The Virginia Mummy (1835) and Dion Bouciault's famous racial melodrama The Octoroon (1859). First situating The Virginia Mummy alongside The Lion of the West, Rebhorn details the close association of the frontiersman and the blackface minstrel on the nineteenth-century stage in terms of the rural cultures on which both drew, the commonalities of their humor and language, and their co-appearance in many dramas. Acknowledging Wildfire's racist proclamations, Rebhorn 
describes Rice's challenge to the racist frontiersman through the slippery character of Ginger Blue. Drawing on the work of Lott, Brooks, and W. T. Lhamon, Rebhorn asserts minstrelsy's "strategic illegibility" (74) as seen in the mummy disguise of Ginger Blue, whose bewilderingly painted body stands in sharp contrast with the decipherable American Indian figure and that of the branded slave or abolitionist. Much rests on this claim, which depends in turn on disputable interpretations of both a rare image of Rice as Ginger Blue and Charles Bird King's portrait of Sequoya. Rebhorn's subsequent reading of Octoroon as self-reflexively puncturing the racial coding of melodramatic suffering through an "amalgamated" performance (white and black but also red) likewise depends on image interpretations that are stimulating, if not completely convincing. After discussing the passionate display of grief and revenge by Wahnotee of Octoroon as challenging melodramatic convention and social propriety, Reborn concludes with an analysis of the "double bill" at P. T. Barnum's American Museum in 1860 of Octoroon and the display of a "creature" known as "What is It?" (113). Focusing on advertisement images of the "both black-and-white" "What is It?," Rebhorn argues that his appearance in the same venues as Octoroon's staging links these two frontier presentations as "aggressively performing another idea of what it means to 'act' American" (119) through the simultaneity of blackness and whiteness. Yet Rebhorn does not consider how the figure is also "red"; "What is It?" dons a peace medal of the kind given by US representatives to American Indian leaders and often worn by the latter in official portraits (as in King's portrait of the "legible" Sequoya).

The final chapter of Staging the Frontier addresses the popularity of frontier dramas in the postbellum era, comparing Daly's Horizon (1871) and Joaquin Miller's Danites in the Sierras (1877) in a way that resonates with the opening juxtaposition of Cody and Mohawk. Daly participated in the postbellum effort to make theater respectable, and Rebhorn compares his actions to civilizing endeavors portrayed in Horizon. In contrast, Miller wrote a gender-bending play reflective of midcentury California's irrepressible heterogeneity and resistant to Daly's Indian-hating, patriarchal vision. Rebhorn summarizes, "To survive on the frontier, Daly insists, communities must be defined by their differences and based on a policy of exclusion; to survive on the frontier, Miller retorts, communities must be defined by their inclusions and based on the linking of differences" (138). These 1870s dramas lay the groundwork for "two distinct types of the performed frontier in the twentieth and twenty-first centuries" (122), and in the conclusion Rebhorn reflects on those two types as exemplified by the infamous pictures of President George W. Bush clearing brush on his 
ranch in Crawford, Texas, in 2005 and by Ang Lee's film Brokeback Mountain of the same year. More specifically, drawing on Bush's frontier performance, Rebhorn develops a reading of Brokeback Mountain as "driv[ing] a wedge into a monolithic incarnation of the frontier" (163) by representing the frontier as both an idyllic space of freedom and a highly repressive site of resource extraction. These two strains have always been present in the western-and, as Rebhorn fruitfully argues, in the seminal frontier dramas of the nineteenth century.

Masculinity is a key term in all the studies reviewed here, whether in McAllister's treatment of stand-up comics on black manhood, Hughes's analysis of the injured veteran, or Rebhorn's exploration of the frontier's white heterosexual hero. In Acts of Manhood, Kippola explores dueling strains of white masculinity in the nineteenth century-namely, "intellectual self-control and passionate action" (3) - by attending to the performance styles and careers of the controlled Edwin Booth and the passionate Forrest, with a closing turn to Forrest acolyte John McCollough. Careful to say in the introduction that "changes in masculine performance should not be read as a teleological progression or decline," Kippola instead asserts that the stage magnified a cultural process by which "a multitude of masculinities simultaneously fought for dominance and recognition" (9). Unfortunately, Acts of Manhood largely overlooks the role of racial performances and performers of color within that multitude of masculinities, an omission that limits its interpretive reach.

The introduction and chapter 1 provide historical and aesthetic context for the treatments of Forrest and Booth to follow, including descriptions of classical and romantic acting styles, associated most directly with John Phillip Kemble and Edmund Kean, respectively, but also as practiced by such stars as Booth's father Junius Brutus Booth and Forrest's rival Charles William Macready. After reviewing masculinity on the early American stage, Kippola identifies 1828 as a turning point in performances of white masculinity, with the election of Andrew Jackson and the symbolic rejection of the classical oratorical style practiced by John Quincy Adams. As Kippola discusses the alternative masculinities represented by the period's most revered orators, including Henry Clay, John C. Calhoun, Daniel Webster, Henry Ward Beecher, and Abraham Lincoln, he troublingly makes a passing reference to Frederick Douglass and does not consider other turning points of the era critical to masculinity such as the Panic of 1837 or the Compromise of 1850. That said, Kippola does an admirable job in chapter 1 of connecting oratorical and theatrical performances to everyday life through popular advice literature. 
Chapter 2 discusses Forrest's masculine style as "a theatrical equivalent of the Jacksonian model" (53), resonating with Rebhorn's characterization and earlier studies by Lawrence Levine and Bruce McConachie, ${ }^{3}$ while chapter 3 recounts the Astor Place Riot of 1849 as the inevitable outcome of conflicting masculinities. According to Kippola, Forrest's passionate expression onstage alienated middle-class viewers and caused him to appear "ungovernable, incapable of self-restraint, and unable to forgive or forget a perceived slight" (58). In vehicles like Robert T. Conrad's Jack Cade (adapted for Forrest in 1841), Forrest "encourag[ed] a dual manhood-a communal manhood of self-restraint and self-sacrifice that supports a self-made manhood rewarding the strong" (88). When thousands of New Yorkers took to the streets in 1849 to protest the appearance at the Astor Place Opera House of Forrest's British rival, Macready, the National Guard ended the matter by opening fire. According to Kippola, the Astor Place Riot "validated upper-class enforcement of a single, genteel masculine image and served as a warning of harsh patriarchal discipline" (116). While he does not insist on one model superseding another, Kippola nonetheless describes a progression in the class-based divide between masculine strains.

Turning to Edwin Booth in chapter 4, Kippola links the actor's "feminized masculinity" to an emerging middle-class culture of restraint that harked back to an eighteenth-century sensibility. In contrast to the Jacksonian Forrest, Booth "assimilated elements of English gentility, and a refinement that was tempered by the fire of experience, into a distinctly American vision of manhood" (145). Of course, Forrest still drew audiences in working-class venues and inspired young thespians. Chapter 5 examines McCullough's career, from his arrival from Ireland at age sixteen to apprenticeship as a second lead to Forrest in the 1860s, development of a new style after studying the Delsarte system with Steele MacKaye, and tragic mental decline because of syphilis. Kippola approaches the career of the genial McCullough as evidence of the long transition away from a Forrestian model, an account that tempers the interpretation of the Astor Place Riot as a defining moment in US theatrical culture.

The conclusion to Acts of Manhood attempts to rectify its general neglect of race in performance by briefly discussing how the theater "affirmed and normalized white masculinity by stigmatizing 'abnormal' others, establishing and enforcing social and gender barriers of excluded men” (173), including American Indians (through redface performance), African Americans (through blackface minstrelsy), and immigrants (through stage Irishmen). While acknowledging the critical role of the racial other to the framing of white masculinity, Kippola does not fully consider the implications of a performative affiliation of white working-class identity with African American culture, nor does he look 
beyond racial mimicry by white men to consider how actors of color performed masculinity to recuperative ends. Such exclusions lead one to believe that Acts of Manhood offers less a performance genealogy of white masculinity on the nineteenth-century stage than a performance genealogy of Forrestian masculinity. What Kippola's book provides - from its remarkable history of Forrest's commandeering of Jack Cade to its careful delineation of Booth's style in contrast to Forrest's to its sympathetic treatment of McCullough's negotiation of his mentor's style - is an account of a star whose physical form and passion compelled and repelled American audiences for decades and who continues to haunt performances of national manhood.

These four performance genealogies drive us back to the stage and outward again, such that, after reading them, one cannot help but find theatrical practice infusing cultural formations of the nineteenth century and beyond. Just as important, these books foster, as Roach would say, a kinesthetic remembrance and imagination of the past by analyzing not only the textual record but also a rich array of images (and in McAllister's work, the audiovisual record). By pushing the reader to understand nineteenth-century cultural formations in strikingly physical, immediate ways, these books affirm the deep relevance of disparaged nineteenth-century modes - racial caricature, melodramatic spectacle, and Romantic histrionics - to performances in the present moment. And by moving from the nineteenth-century into the present, to varying extents, these books insist that a physical comprehension of the past arises not only from careful research and evocative writing but also from a performance legacy at play in the present.

\section{Notes}

1. See Eric Lott, Love and Theft: Blackface Minstrelsy and the American Working Class (New York: Oxford University Press, 1993), chap. 8; Linda Williams, Playing the Race Card: Melodramas of Black and White from Uncle Tom to O. J. Simpson (Princeton, NJ: Princeton University Press, 2001), chap. 2; Sarah Meer, Uncle Tom Mania: Slavery, Minstrelsy, and Transatlantic Culture in the 1850s (Athens: University of Georgia Press, 2005); David S. Reynolds, Mightier Than the Sword: Uncle Tom's Cabin and the Battle for America (New York: Norton, 2011), chaps. 5-6; John W. Frick, Uncle Tom's Cabin on the American Stage and Screen (New York: Palgrave Macmillan, 2012); and Stephen Railton, "Uncle Tom's Cabin and American Culture," http://utc.iath.virginia.edu/ (accessed December 18, 2013).

2. Joseph R. Roach, Cities of the Dead: Circum-Atlantic Performance (New York: Columbia University Press, 1996), 25, 26. Of the books under review, those by Rebhorn and Hughes draw most explicitly on Roach's work.

3. See Lawrence W. Levine, Highbrow/Lowbrow: The Emergence of Cultural Hierarchy in America (Cambridge, MA: Harvard University Press, 1988); Bruce A. McConachie, Melodramatic Formations: American Theatre and Society, 1820-1870 (Iowa City: University of Iowa Press, 1992). 